\title{
Main Characteristics of Water Regime of the Phreatic Aquifer in Šid Municipality (Vojvodina, Serbia)
}

\author{
Milošević Dragan ${ }^{A *}$, Pavić Dragoslavi, Mészáros Minucsér ${ }^{B}$, Dolinaj Dragan ${ }^{A}$, Savić Stevan ${ }^{A}$ \\ Received: September 2013 | Revised: September 2013 | Accepted: September 2013
}

\begin{abstract}
Šid municipality is situated in the south-western part of Autonomous Province of Vojvodina (northwestern Serbia). Four geomorphological units are represented on its territory: The Fruška Gora Mountain, Srem loess plateau, Srem loess terrace and alluvial plains of river Sava and its tributaries.The largest part of Šid municipality consists of the early Quaternary sediments of intergranular porosity which form the water collecting environment for the phreatic aquifer. Because of the incomplete database, the main goals of this paper are restricted on defining basic characteristics of water regime of the phreatic aquifer in Šid municipality and their causal connection with the climatic, hydrological and anthropogenic factors. The results showed the prevailing presence of climatic type of the phreatic aquifer water regime in the study area, with fragmentary presence of climatic-hydrological type near rivers and climatic-anthropogenic type near and inside the city of Šid. Special emphasis is given to the inadequate phreatic water table depth monitoring in the study area. This situation prevents the detailed study of the phreatic aquifer water regime and estimating the exact directions of its outputs, which creates a significant problem that needs to be solved in the near future.
\end{abstract}

Key words: phreatic aquifer, water regime, Šid municipality, Srem, Vojvodina, Serbia

\section{Introduction}

Phreatic (unconfined, free, first, shallow) aquifer is the shallowest water horizon which most often appears in the sediments of intergranular porosity. Its formation and distribution primarily depends on the processes whose character is defined by numerous natural and anthropogenic factors. Among the natural factors hydrogeological, climatic, pedological, geomorphological and phytogeographic factors are the most significant (Pavić et al., 2012). However, anthropogenic factors can modify the natural regime of the phreatic aquifer in areas where hydrotechnical works were performed (Pavić, 2006; Pavić et al., 2006; Pen- nington, Cech, 2010). The fluctuations of the water table of primary aquifer is, above all, a result of unsteady input and output of water which is directly dependent on the distribution of precipitation and temperatures of air and soil and the quantity of evaporation (Pavić et al., 2006).

The phreatic aquifer represents highly significant natural resource of water for agricultural production in areas like Vojvodina. In contrast, during wetter periods, a negative consequence of high phreatic aquifer water table occurs when phreatic water reaches the topographic surface causing damages, e.g. floods of arable land and lower parts of settlements. Numerous authors have been dealing with the problem of water

A Climatology and Hydrology Research Centre, Faculty of Science, University of Novi Sad; Trg Dositeja Obradovića 3, 21000 Novi Sad, Serbia

B Center for Spatial Information of Vojvodina Province, Faculty of Sciences, University of Novi Sad, Trg Dositeja Obradovića 3, 21000 Novi Sad, Serbia

* Corresponding author: Dragan Milošević, e-mail: draganmilosevic88@yahoo.com 
regime of the phreatic aquifer and impacts of natural and anthropogenic factors on its formation and distribution in different parts of Vojvodina (Petrović et al., 1973; Milošev et al., 1977; Vasileva, 1978; Bogdanović, 1982; Dedić et al., 1984; Stojšić, 1994; Marković, Bogdanović, 1995; Marković, 1996; Davidović et al., 2000; Pavić, 2006; Pavić et al., 2006; 2012).

The main goals of this paper are to present the major characteristics of water regime of phreatic aquifer in Šid municipality and to highlight the problems with inadequate monitoring of water table depth in the area (non-continuous measurements and small number of wells). Also, one of the aims is to emphasis the need for establishing a denser network of monitoring wells and more frequent measurements of water table level of the phreatic aquifer for the purpose of more detailed research.

\section{StudyArea}

Šid municipality is situated in south-western part of Autonomous Province of Vojvodina. It occupies the western part of Srem, one of the three territorial units of AP Vojvodina (Figure 1). The territory of Šid municipality borders the Republic of Croatia to the north, west and south-west, the Republic of Bosnia and Herzegovina (Republic of Srpska) to the south-west, the municipality of Sremska Mitrovica to the east and the municipality of Bačka Palanka to the north-east. Šid municipality covers $687 \mathrm{~km}^{2}$ (Đurčić, 1984) which is $18.7 \%$ of Srem territory or $3.2 \%$ of the territory of AP Vojvodina. Beside the urban center of Sid (14,893 inhabitants), eightteen other rural settlements are located in the research area with 19,295 inhabitants living in them (Statistical Office of the Republic of Serbia, 2011).

Quaternary sediments (loess, sand, gravel, clay, etc.) cover the largest part of the investigated area. The territory of Šid municipality stretches on four relief units: the Fruška gora Mountain, Srem loess plateau, Srem loess terrace and alluvial plains of river Sava and its tributaries (given its location from north to south). The Fruška Gora Mountain stretches for $20 \mathrm{~km}$ in the northern part of the investigated territory in west-east direction with the highest peak Liske (294 m). Two fluvial terraces (240-270 $\mathrm{m}$ and $200-220 \mathrm{~m}$ ) are present

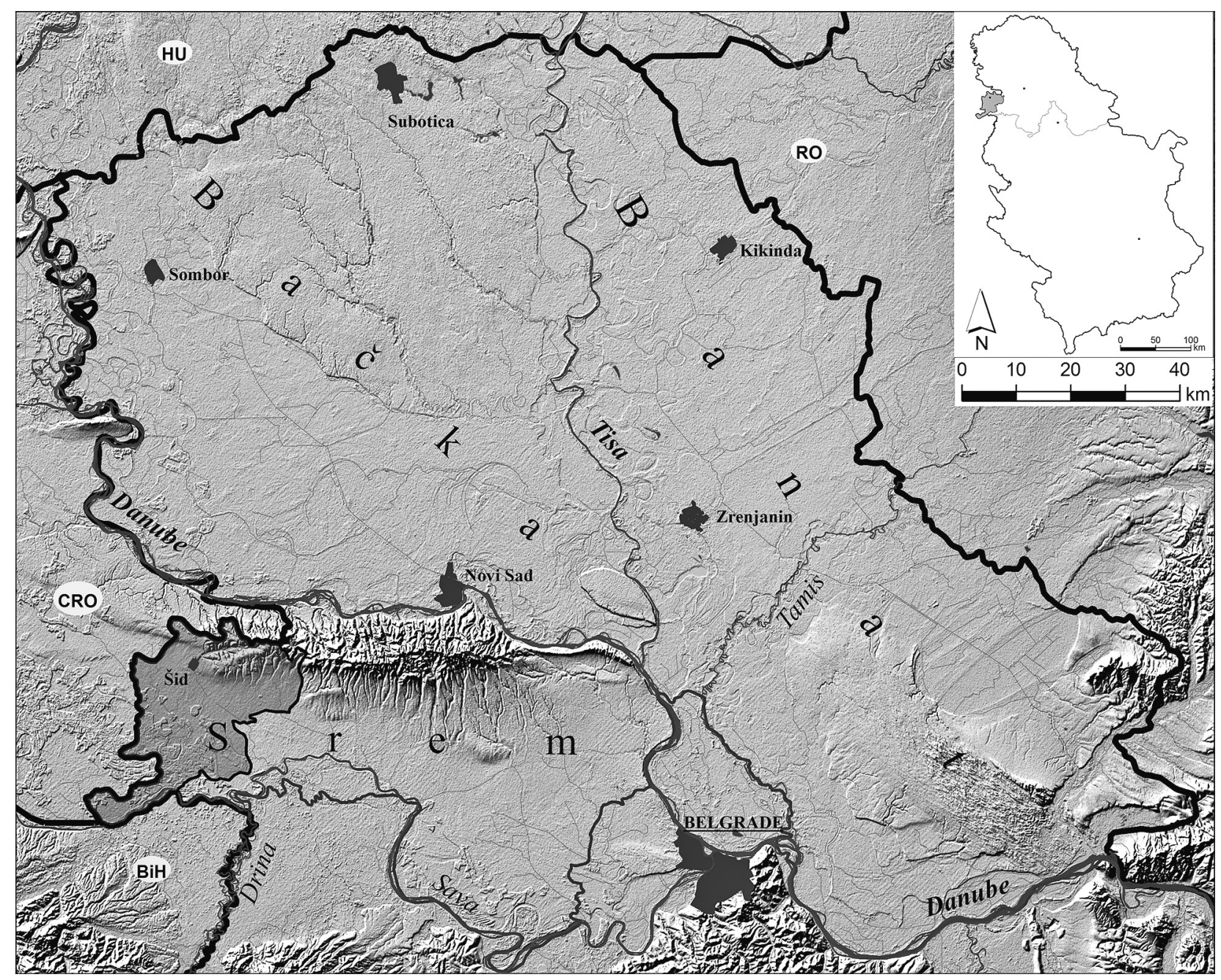

Figure 1. Geographical position of Šid municipality in AP Vojvodina and Serbia 
on the slopes of Fruška Gora Mountain (Milić, 1973). The eolian landforms of relief in Šid municipality are represented with two loess plateaus (Srem loess plateau) located on the slopes of Fruška Gora, with different heights: 130-150 m and 110-120 m (Milić, 1973). The Srem loess terrace is located south from Srem loess plateau and is lower that it from 10 to $20 \mathrm{~m}$ (Đurčić, 1984). The lowest and largest part of Šid municipality is covered with the alluvial plain deposits of river Sava and its tributaries (height around $80-85 \mathrm{~m}$ ) in the south-western part of the investigated area.

The Šid municipality is situated in the area of continental climate (Rakićević, 1980; Ducić, Radovanović, 2005). According to average annual air temperatures for the perennial period (1949-2011) at the Sremska Mitrovica meteorological station $\left(45^{\circ} \mathrm{O} 6^{\prime} \mathrm{N}\right.$ and $19^{\circ} 33^{\prime}$ E, $82 \mathrm{~m}$ ), January is the coldest month and the only one with negative mean monthly air temperature $\left(-0.4^{\circ} \mathrm{C}\right)$, whereas July is the warmest month $\left(21.3^{\circ} \mathrm{C}\right)$. The mean monthly air temperature increases continually from January to July, and then decreases continually to the end of the year. The mean annual air temperature for perennial periods is $11.1^{\circ} \mathrm{C}$. Mean air temperature in winter is $0.9^{\circ} \mathrm{C}$, in spring $11.5^{\circ} \mathrm{C}$, in summer $20.6^{\circ} \mathrm{C}$ and in autumn $11.3^{\circ} \mathrm{C}$. Vegetation period has mean air temperature of $16.9^{\circ} \mathrm{C}$. The meteorological station Sremska Mitrovica is located less than $20 \mathrm{~km}$ to the east from the investigated area and was selected for meteorological parameter investigation for the territory of Šid municipality because the meteorological station in Šid stopped working in 1990.

Perennial data on precipitation (1949-2011) from the meteorological station Sremska Mitrovica indicate prominently uneven annual distribution. The month with least precipitation is February with $36.1 \mathrm{~mm}$ while June is month with the most precipitation (84.3 $\mathrm{mm})$. Mean monthly precipitation continually increases from February minimum towards its maximum in June and then continually decreases to September. In October and November precipitation shows a slight increase and then continually decreases towards February minimum. Mean annual precipitation for the meteorological station Sremska Mitrovica is $624.6 \mathrm{~mm}$. The maximum precipitation occurs in summer $(201.6 \mathrm{~mm})$, followed by autumn (148.0 $\mathrm{mm})$, spring $(146.2 \mathrm{~mm})$ and the minimum in winter $(128.8 \mathrm{~mm})$. Mean precipitation for the vegetation period is $402.5 \mathrm{~mm}$.

Surface waters of Šid municipality are represented by natural water courses, canals, artificial lakes and swamps. The lower courses of rivers Sava (16.5 $\mathrm{km})$, Bosut $(38 \mathrm{~km})$ and Studva $(18 \mathrm{~km})$ flow through the area covered in the study (Đurčić, 1984). Among the canalized courses, the most important are Šidina (Šarkudin) (40 km), Lipovac, Boris, Vagant, Vrtić and Eastern (General) channel. The artificial lakes are rep- resented by small accumulations of water on Moharač stream (Lake Moharač, $0,55 \mathrm{~km}^{2}$ ), on Šidina stream (Lake Sot, 0,22 $\mathrm{km}^{2}$ ) (Davidović et al., 2000) and on Bruje stream (Lake Bruje, $0,12 \mathrm{~km}^{2}$ ) (Bugarčić, 2007). Swamps are located in south-western part of the investigated area in the alluvial plain of river Sava and its tributaries. The largest swamps are Breg and Slezen swamp near village Morović (Davidović et al., 2000).

Within the study area, there is a heterogeneous soil cover represented by various soil types: pseudogley-lessive, alluvial loam-clayish soils, hydromorphic mineral gleyed soil sporadically salinized, chernozemlike calcareous meadow soils, chernozem calcareous, chernozem with signs of swamping in the past, chernozems with various degree of brownization or with spots of solođi soil, etc. (Živković et al., 1972a; Živković et al., 1972b). The largest part of the study area is covered with agricultural vegetation (wheat, corn, etc.), while on the slopes of Fruška Gora and in the alluvial plain near river Sava and its tributaries, deciduous forest is present (oak, tilia, etc.) (Đurčić, 1984).

\section{Materials and methods}

The data about the observations of the phreatic water table depth, taken from the database of Water management company "Šidina" from Šid which are part of Water management company "Vode Vojvodine", have been used as basic material for the analysis of water regime of the phreatic aquifer in the study area. A systematic observation of phreatic water table depth $(2-3$ times monthly) on the territory of Vojvodina started in the second half of the $20^{\text {th }}$ century. Only on the territory of Šid municipality more than 40 monitoring wells (piezometers) were established. However, in the following years, the observations were not carried regularly in a number of wells, whereas majority of wells stopped functioning completely.

The wells are unevenly distributed on the investigated territory and the data obtained covers two periods (1981-1988 and 2001-2011). During the first investigated period more than 40 wells were working, but 38 wells were chosen for the research because they had adequate data (less than $10 \%$ of missing data). In the alluvial plain of river Sava and its tributaries 32 wells are present (near village Jamena there are 12 wells, but also wells near villages Višnjićevo, Batrovci, Adaševci, Vašica, Ilinci, Gibarac, Bačinci and Kukujevci), three wells are located on the Srem loess terrace $\left(\breve{S}_{-}-32, \mathrm{~B}-40\right.$ and E-44) and three wells are located on the Srem loess plateau (BE-33, BE-35 and BE-36). During the second investigated period, there is still an uneven distribution of monitoring wells with significant decrease in their number: six wells are located in the al- 


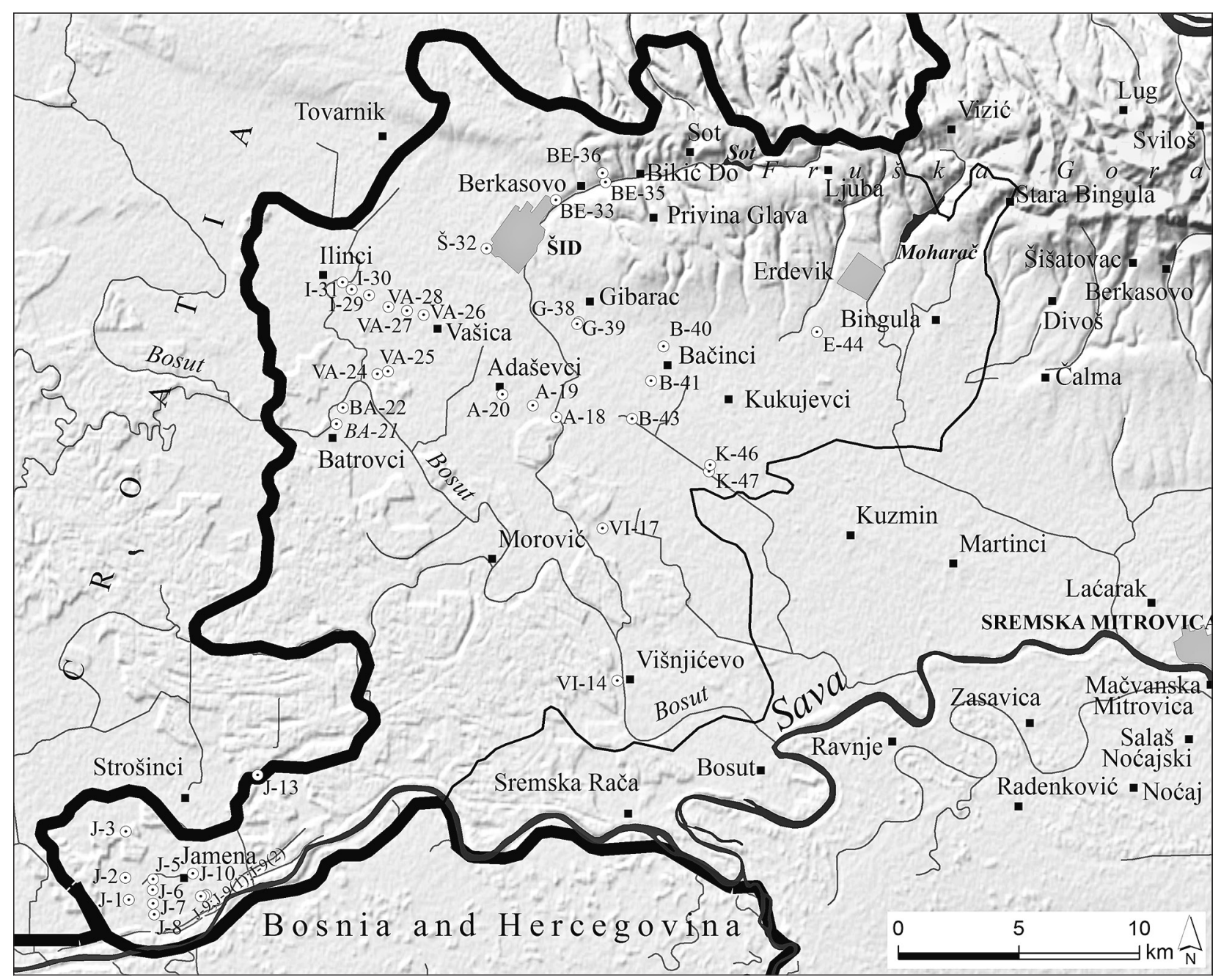

Figure 2. Position of the analysed wells in both periods; italic - well (BA-21) used only in the period 2001-2011

luvial plain (A-19, BA-21, BA-22, VA-27, I-30 and G-39), one on Srem loess terrace $\left(\check{S}_{-}-32\right)$ and one on Srem loess plateau (BE-35). The reason for establishing a monitoring network of wells with such uneven distribution is that the alluvial plain is at biggest risk from floods so the majority of wells were established there (Figure 2).

Beside the above mentioned basic materials, rich cartographic material (topographic, geological, geomorphological and pedological maps, etc.) and reference resources were used in this work, as well.

The main characteristics of water regime of the phreatic aquifer in the study area are defined by the analysis of annual variation of mean monthly phreatic aquifer water table depths for 38 monitoring wells in the first investigated period (1981-1988, including well VI-17 with slightly moved monitoring period 1980-1987) and from eight monitoring wells in the second investigated period (2001-2011, including well $\breve{S}_{-32}$ with shorter monitoring period 2000-2007). Data was gathered during these periods with a pause in the data gathering of phreatic water table depths during the ' 9 os because of the bad political situation during that time (war in Yugoslavia, international sanctions,
NATO bombing). Only 10 monitoring wells are working at present of which eight wells had missing data less than $10 \%$.

The estimation of the influence of dominant climatic factors on the phreatic water regime of the study area has been done through the comparison of annual variation of the mean monthly values of the water balance of climatic factors with the annual variation of the mean monthly phreatic water table levels for representative wells (for investigated periods). The water balance of the climatic factors represents the difference between the total precipitation and evapotranspiration. The mean monthly values of potential evapotranspiration were calculated by the Turc formula for the meteorological station Sremska Mitrovica. The Turc formula is as follows (Turc, 1961):

$$
E T p=0.40 \times\left(I_{g}+50\right) \times[T \div(T+15)]
$$

ETp potential evapotranspiration for the given month $(\mathrm{mm})$

$T$ average monthly air temperature (oC)

$I_{g} \quad$ intensity of sun radiation $\left(\mathrm{gr} \mathrm{cal} / \mathrm{cm}^{2}\right)$ 
The perennial data about mean annual and monthly air temperature and precipitation quantities for meteorological station Sremska Mitrovica was taken from the Yearbooks of Republic Hydrometeorological Service of Serbia. Annual and monthly values of intensity of Sun radiation was used from Stamenković (2009) for Belgrade which is located on similar latitude as Sremska Mitrovica.

The estimation of the influence of dominant hydrological factors on the phreatic water regime of the study area has been done through the comparison of annual variation of the mean monthly values of the water level of river Sava at surface water station Sremska Mitrovica with the annual variation of the mean monthly phreatic water table levels for representative wells (for investigated periods).

\section{Results and discussion}

The phreatic aquifer is continuously present on the territory of Šid municipality due to favourable hydrogeological conditions. This is possible because of the presence of Quaternary sediments of intergranular porosity (aluvial deposits, terrace and typical loess) which represent water colecting environment in the investigated area (Živković et al., 1972a). In the bottom, at the depths ranging from several meters to several dozen meters,impermeable clay sediments represent a barrier for the water to move downwards and so the lower boundary of the phreatic aquifer is formed. Pedological conditions on the investigated territory (alluvial soils, chernozem soils, etc.) are also favourable for the filtration of water to the aquifer.

Characteristics of the water regime of phreatic aquifer may be observed through the analysis of the water table level oscillations and estimation of the size and forms of various factors that cause oscillations. According to dominant natural and anthropogenic factors, Stojšić (1994) classifies four types of water regime of the phreatic aquifer in Vojvodina:

- climatic type - as the most frequent, it is formed under the influence of climatic factor, primarily precipitation and temperature conditions;

- hydrological type - formed under the influence of large water courses (the Danube, the Tisa and the Sava);

- climatic-hydrological type - formed under joint influence of climatic and hydrologic factors in their influence transfer zone;

- climatic-anthropogenic and hydrological-anthropogenic type - formed by artificial modification of natural regime (melioration, hydrotechnical measures, etc.).
As it has been already explained, the data about the depths of the phreatic water table have been used from the observations on 38 monitoring wells during the first investigated period (1981-1988), including one well (VI-17) with slightly different investigated period (1981-1987). The above mentioned problems related with uneven distribution of wells and short investigated period prevent a more serious analysis of the phreatic aquifer regime of the study area. However, the wells may offer general overview of annual variations of water table depths and the range of its annual oscillations in different parts of the study area. The analysis of the data for the period 1981-1988 (Table 1) provided following conclusions:

- minimun mean mothly depths of phreatic water table within the study area most freuqently occur in spring (March and Apil). The March minimum is registered on 18 wells (mostly in alluvial plain), the April minimum is registered on 15 wells (mostly in alluvial plain), while identical minimum depths values in two months (March-April) occur on well VA-28 and in April-June on well VI-17. Minimum monthly depth values, slightly delayed, occur in May on two wells, one located on Srem loess terrace (E-44) and one located on Srem loess plateau (BE-33) and in July on well Š-32 located in the only city on the investigated territory which lies on Srem loess terrace.

- maximum mean monthly depths of phreatic water table within the study area most frequently occur in autumn and winter, especially during November, December and October. The November maximum is registered on 15 wells (mostly in alluvial plain), the December maximum is registered on 12 wells (mostly in alluvial plain and on Srem loess terrace) and the October maximum on nine wells (all of them are located in alluvial plain). Identical maximum depth values in two months (October-November) occur on one well located on Srem loess plateau (BE-35). On one well located in alluvial plain (B-41) is registered slightly moved September maximum of phreatic water table depth.

- the smallest phreatic water table depths are registered in alluvial plain with mean annual depths ranging from $103 \mathrm{~cm}$ to $379 \mathrm{~cm}$ on 32 wells. On Srem loess terrace depths of phreatic water table are bigger and range from $253 \mathrm{~cm}$ to $675 \mathrm{~cm}$ on three wells. The biggest phreatic water table depth value is registered on well BE-35 located on Srem loess plateau because of its high elevation and possible deeper location of impermeable clay layer in the bottom. On other two wells located on this geomorphological unit phreatic water table depths range from $116 \mathrm{~cm}$ to $159 \mathrm{~cm}$. 
हैं

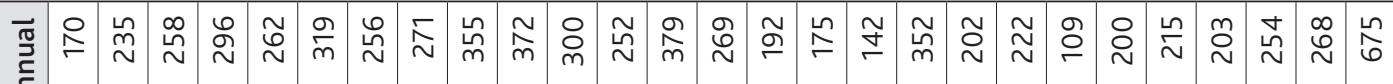
$\frac{10}{4}$

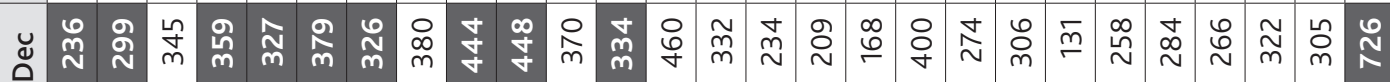

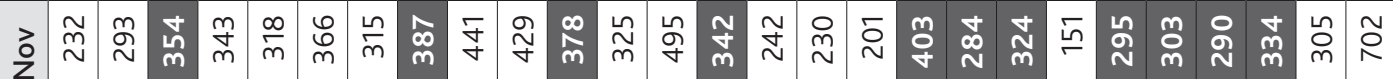

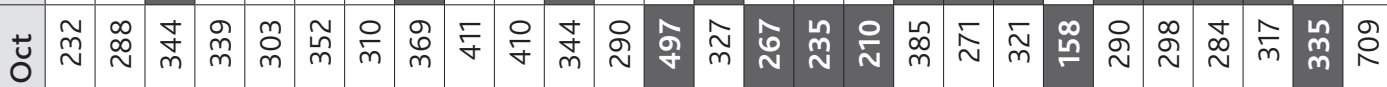

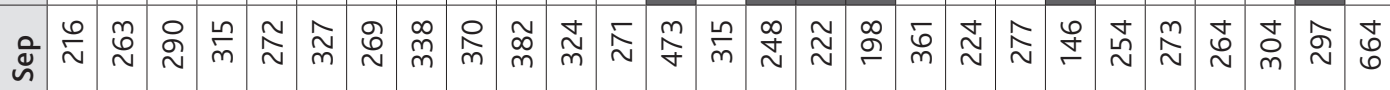

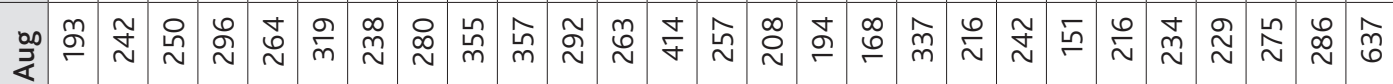

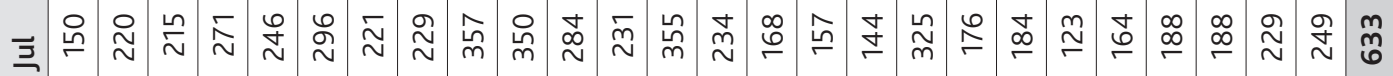

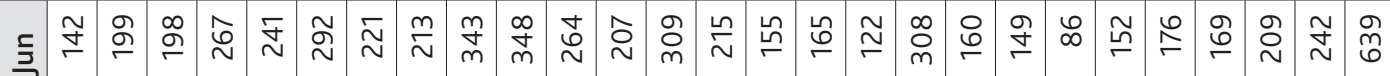

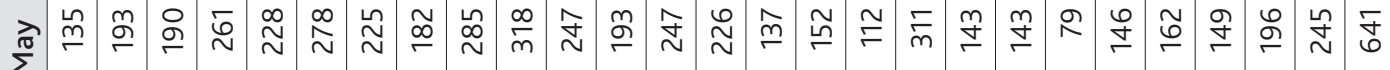

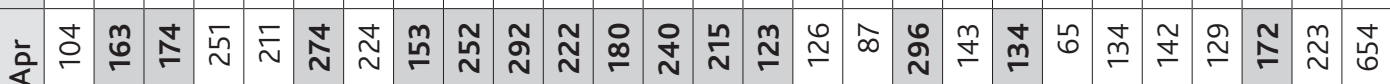

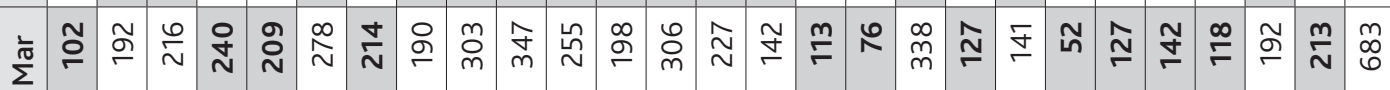
\&

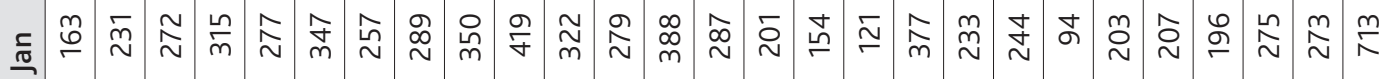

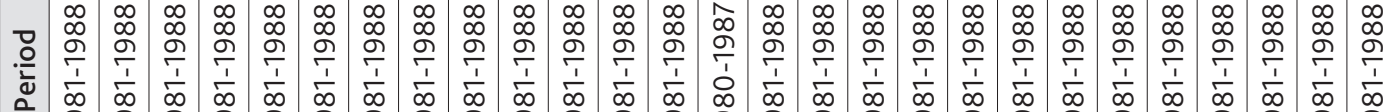

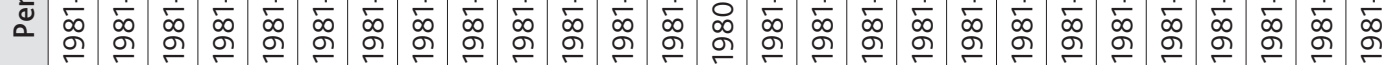




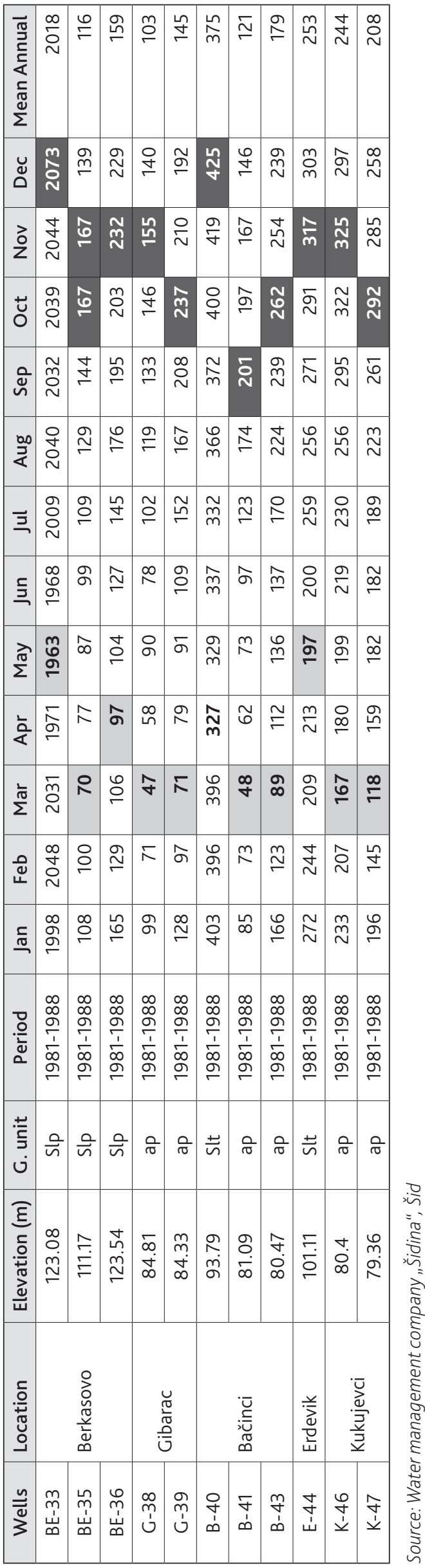

- annual amplitudes of mean monthly water table depths have smallest values on Srem loess terrace and range from $93 \mathrm{~cm}\left(\breve{S}_{-32}\right)$ to $120 \mathrm{~cm}(\mathrm{E}-44)$, than at the Srem loess plateau range from $97 \mathrm{~cm}$ (BE$35)$ to $135 \mathrm{~cm}$ (BE-36). The highest values of annual amplitudes are present on wells located in alluvial plain and range from $105 \mathrm{~cm}$ (J-7) to $256 \mathrm{~cm}$ (VI-14). Annual amplitudes for absolute extreme monthly depths in perennial period are significantly higher.

Data was analized for only eight remaining wells in the second investigated period (2001-2011), including one well (ك̌-32) with a shorter analyzed period (20002007) but it was choosen for the analysis because of its location in the city of Šid. The analysis of the data for the period 2001-2011 (Table 2) provided following conclusions:

- minimum mean mothly depths of phreatic water table within the study area most frequently occur in spring (April and March). The April minimum is registered on four wells in alluvial plain of river Sava and its tributaries. The March minimum is registered on three wells (two in alluvial plain and one on Srem loess plateau). The slightly delayed June minimum occurs on well $\breve{S}_{-32}$ located on Srem loess terrace.

- maximum mean monthly depths of phreatic water table within the study area occur in autumn (October and September). The October maximum is registered on six wells (five in alluvial plain and one on Srem loess terrace). The September maximum is registered on two wells, one in alluvial plain (VA$27)$ and one on Srem loess plateau (BE-35).

- the smallest phreatic water table depths are registered on Srem loess plateau with mean annual depth on well BE-35 $(35 \mathrm{~cm})$. Bigger phreatic water table depths are registered in alluvial plain ranging from 106 (GI-39) to $294 \mathrm{~cm}$ (BA-22). The biggest depth value is registered on well $\check{S}_{-32}(644 \mathrm{~cm})$ located on Srem loess terrace.

- annual amplitudes of mean monthly water table depths have highest values in alluvial plain ranging from $73 \mathrm{~cm}(\mathrm{G}-39)$ to $180 \mathrm{~cm}(\mathrm{I}-30)$. At Srem loess terrace annual amplitude is smaller $\left(\breve{S}_{-} 32,67 \mathrm{~cm}\right)$. The smallest value of annual amplitude of mean monthly water table depths is registered at well BE$35(52 \mathrm{~cm})$ located on Srem loess plateau. Annual amplitudes for absolute extreme monthly depths in perennial period are significantly higher.

Two investigated periods were compared (mean monthly and mean annual values for the period 20012011 minus mean monthly and mean annual values for the period 1981-1988) for the wells that were functioning in both periods. Decreasing phreatic water ta- 

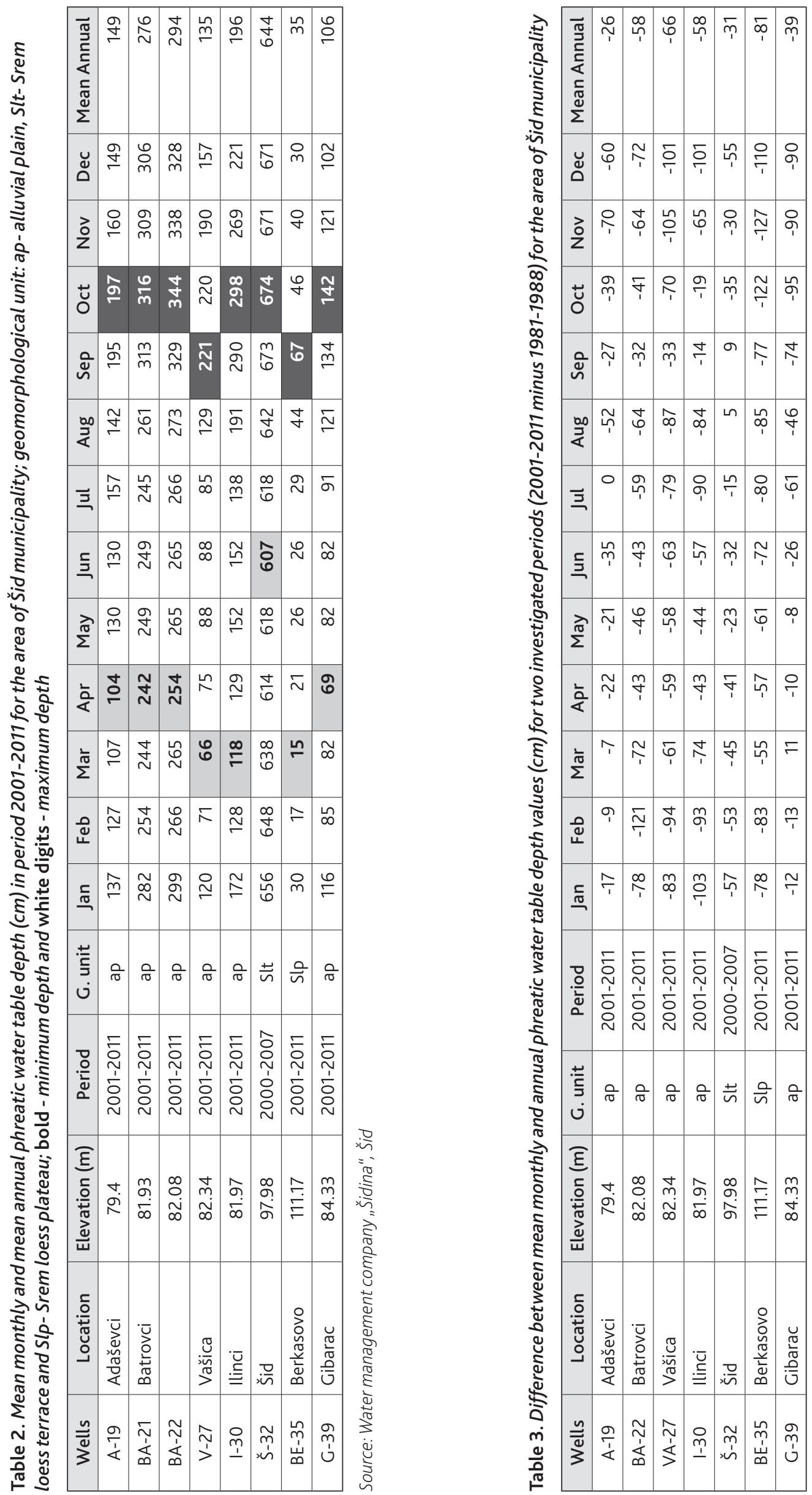
ble depth, e.a. phreatic water is getting closer to the surface was registered on all wells in the second investigated period (Table 3 ). Phreatic water table depth decrease on annual level was from $26 \mathrm{~cm}(\mathrm{~A}-19)$ to $66 \mathrm{~cm}$ (VA-27) in alluvial plain, while at Srem loess terrace it was $31 \mathrm{~cm}$ on well $\breve{S}_{-32}$. The biggest phreatic water table depth decrease occured on well BE-35 $(81 \mathrm{~cm}) \mathrm{lo}-$ cated on Srem loess plateau. The registered decrease of phreatic water table depth on all wells could be a concequence of higher precipitation quantities during period 2001-2011 (649 $\mathrm{mm})$ with regard to earlier period 1981-1988 (588 mm), while water level of River Sava had about the same value in both periods (approximately $270 \mathrm{~cm}$ ).

The data about mean monthly phreatic water table depths presented in Table 1 and Table 2 indicate the dominance of climatic factors and prevailing climatic type of water regime of the phreatic aquifer in the study area. This was also confirmed by comparative analysis of annual variations of mean monthly values of water balance of climatic factors for the meteorological station Sremska Mitrovica and annual variation of mean monthly phreatic water table level for representative wells. Near the Sava river and its tributaries (Bosut and Studva rivers), hydrological factor is also present, so combined climatic-hydrological water regime type could be distinguished on the wells near them. The precise border where climatic or hydrological factors dominate could not be distinguished from avalaible, scarce data. Also it is important to consider that the study area is mostly agricultural area where measures taken in agricultural production (melioration, irrigation, etc.) could modificate natural water regime characteristics.

On higher geomorphological units (Srem loess plateau and Srem loess terrace) the climatic factor domi- nates the water regime of the phreatic aquifer. Namely, the highest monthly water table levels in spring reaching their maximum in March (BE-35 on Srem loess plateau) and May (E-44 on Srem loess terrace) are the result of the prevailing positive climatic water balance between November and March. The lowest mean monthly water table levels in autumn reaching their minimums in period October-November (BE-35) (Figure 3) and November (E-44) (Figure 4) are the result of negative climatic water balance between April and October.

In the alluvial plain of the Sava river and its tributaries as the lowest relief unit in the investigated area, beside climatic, hydrological factors also influence water regime characteristics of the phreatic aquifer on investigated wells, especially near the Sava, Bosut and Studva rivers. It is hard to distinguish the strength of influence of the major hydrological factor in alluvial plain (river Sava) because the highest water level on this river (April) coincide with positive spring water balance of climatic factors. In alluvial plain climatichydrological water regime of phreatic aquifer could be distinguished, especially near river Sava (Figure 5) while moving away from it and its tributaries climatic factor becomes more dominant.

Considering that the biggest part of the Šid municipality is an agricultural area, antropogenic factors can alter the water regime characteristics of phreatic aquifer. In the settlements antropogenic factors can change natural annual and monthly water level oscillations of phreatic aquifer. This is registered on well $\check{S}_{\text {-32 }}$ where maximum water level is moved from two (June, period 2001-2007) (Figure 6) to three months (July, period 1981-1988) because of the added, antropogenic feeding of aquifer with water in spring and summer.

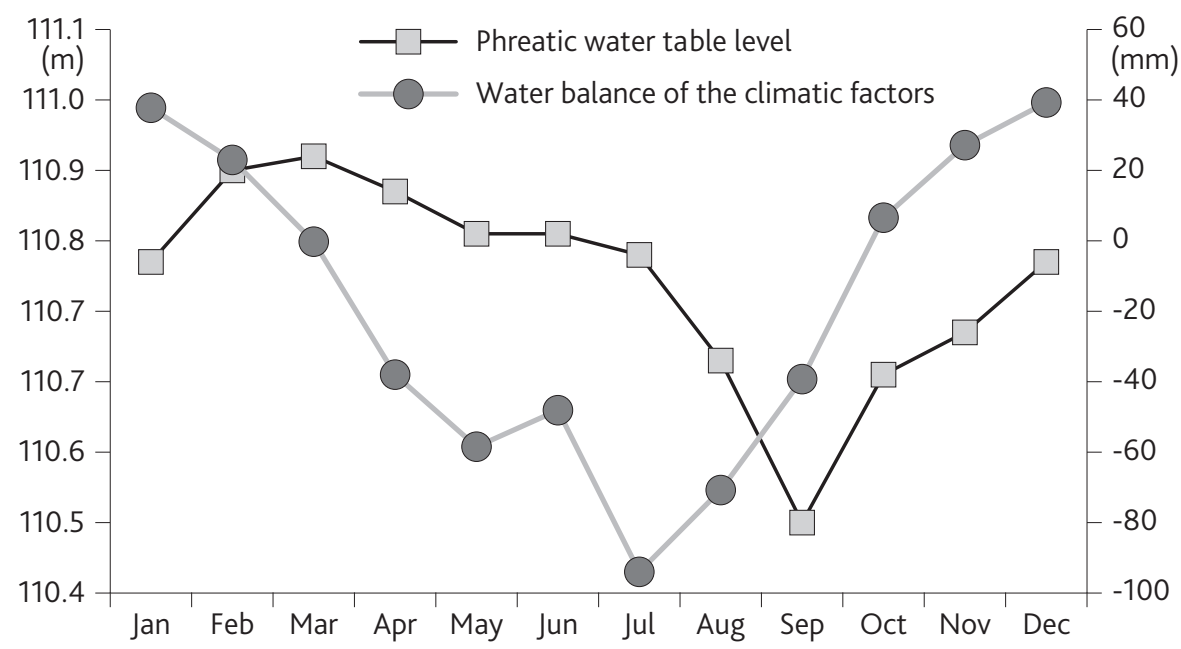

Figure 3. Ratio between mean monthly values of water balance of the climatic factors for meteorological station Sremska Mitrovica and mean monthly phreatic water table level at well BE-35 (Srem loess plateau) in the period 2001-2011 


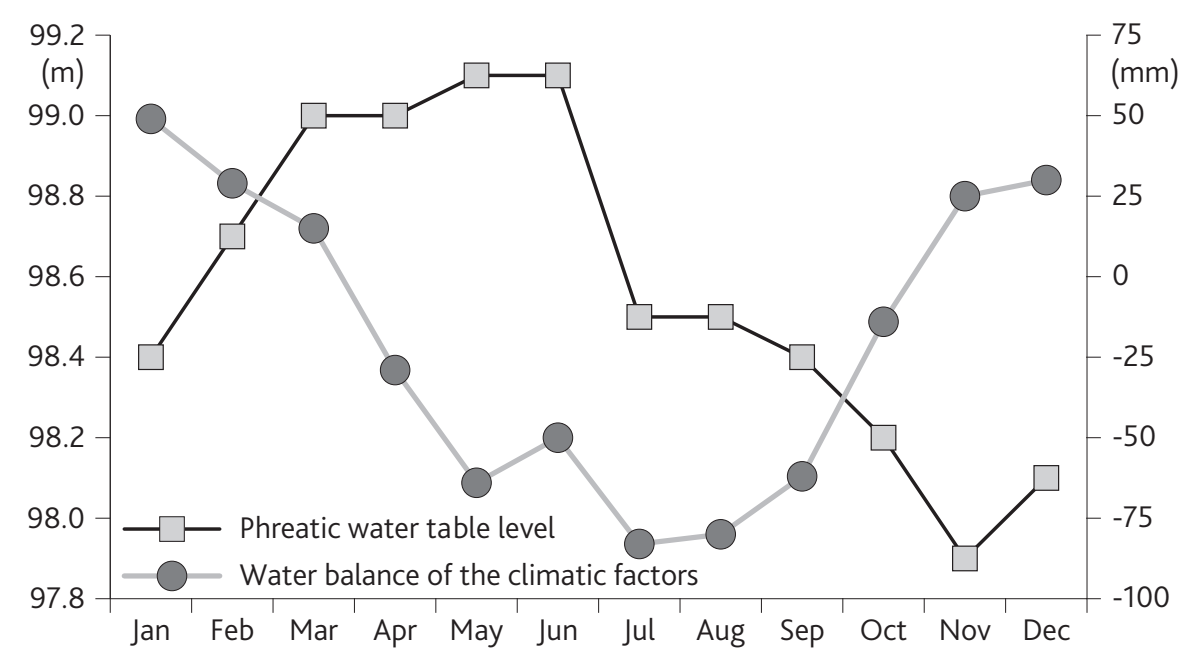

Figure 4. Ratio between mean monthly values of water balance of the climatic factors for meteorological station Sremska Mitrovica and mean monthly phreatic water table level at well E-44 (Srem loess terrace) in the period 1981-1988
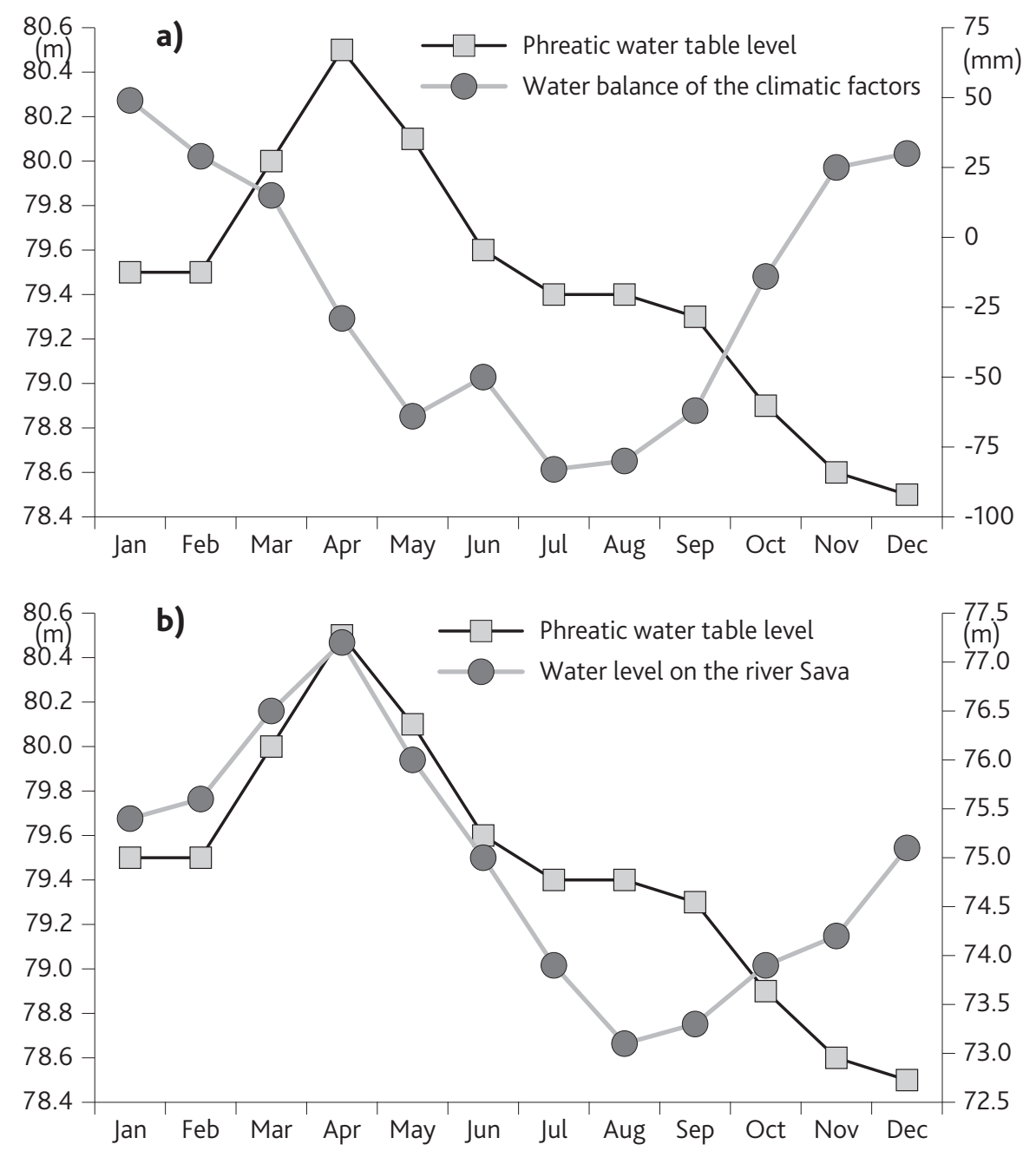

Figure 5. a) ratio between mean monthly phreatic water table level at well J-9(1) (alluvial plain) and mean monthly values of water balance of the climatic factors for meteorological station Sremska Mitrovica in the period 1981-1988 and b) ratio between mean monthly phreatic water table level at well J-9(1) (alluvial plain) and mean monthly values of water level of river Sava on surface water station Sremska Mitrovica in the period 1981-1988 


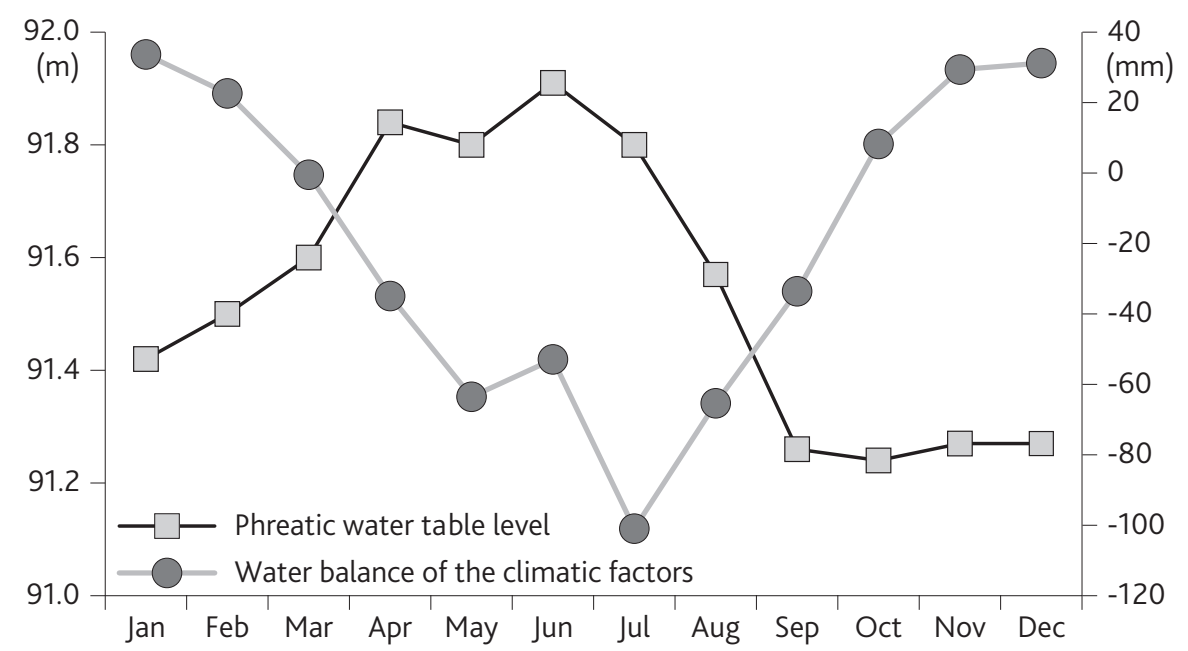

Figure 6. Ratio between mean monthly values of water balance of the climatic factors for meteorological station Sremska Mitrovica and mean monthly phreatic water table level at well Š-32 (Srem loess terrace) in the period 2001-2007

\section{Conclusion}

In the final remarks it is necessary to highlight that the results of the research in this paper, obtained on scarce data on depths of phreatic water table level, provided only a general overview of the main characteristics of the phreatic aquifer water regime in Šid municipality. In fact, the results indicate the dominance of climatic factor and prevailing presence of climatic type of the phreatic aquifer water regime in the study area. The area of Šid municipality has artificial lakes, rivers, canals, swamps, eolian relief forms, versatile soil and vegetation cover. Also, the area is primarily agricultural with application of melioration and irrigation/drainage measures and has one urban area. This is enough to conclude that there are also other factors (hydrological and anthropogenic) that modify at least secondary or fragmentary and influence the formation of the water regime characteristics of the phreatic aquifer. It could be stated that climatic-hydrological type of the phreatic aquifer water regime exist near rivers Sava, Bosut and Studva while climatic-anthropogenic type of the phreatic aquifer water regime exist at least in and near the city of Šid.

In order to estimate more precisely the size of influence of the above-mentioned factors and presence and border zones between types of water regime of the phreatic aquifer it would be necessary to establish a much more serious system of monitoring wells of the phreatic aquifer. Namely, with the establishment of a larger number of monitoring wells, which would cover the research area with a more frequent water ta- ble level monitoring (according to the current methodology in Šid municipality, the depths are monitored monthly twice), a more realistic insight in the phreatic aquifer water regime and the strength of influence of individual factors on its forming in various parts of the research area would be obtained.

There are several reasons to justify a more detailed approach in monitoring and studying the phreatic aquifer in Šid municipality. Above all, because the Srem loess plateau, Srem loess terrace and alluvial plain of river Sava and its tributaries are water rich collecting areas of phreatic groundwater. In addition, the phreatic aquifer is a significant natural resource for a primarily agricultural area, and also because of the need for timely prevention measures for disasters and damages caused by flooding of arable land and settlements due to increase in phreatic water table during extremely wet periods.

\section{Acknowledgements}

This paper was realised as a part of the project "Biosensing Technologies and Global System for Long-Term Research and Integrated Management of Ecosystems" (43002) financed by the Ministry of Education, Science and Technological Development of the Republic of Serbia. First author is a scholar from the Ministry of Education, Science and Technological Development of the Republic of Serbia. Special thanks goes to the employees of the Water management company "Šidina" from Šid, especially to Ms Snežana Ranisavljević for her help with acquiring necessary data for this research. 


\section{References}

Bogdanović, Ž. 1982. Hydrological problems of Srem. Faculty of Sciences, Institute of Geography, Novi Sad, 178 pp. (in Serbian)

Bugarčić, P. 2007. Geographical characteristics and functions of artificial lakes in Vojvodina. Faculty of Science, Institute of Geography, Novi Sad, 134 pp. (in Serbian)

Davidović, R., Bogdanović, Ž., Miljković, Lj., Bugarski, D., Tomić, P., Plavša, J., Lazić, L. 1998. Relief of Srem. Faculty of Science, Institute of Geography, Novi Sad, 90 pp. (in Serbian).

Davidović, R., Miljković, Lj., Marković, S., Tomić, P., Bugarski, D., Plavša, J., Bogdanović, Ž., Lazić, L. 200o. Waters of Srem. Faculty of Science, Institute of Geography, Novi Sad, 112 pp. (in Serbian with English summary).

Dedić T., Josipović, J., Stojšić, M. 1984. Influence of the Tisa to the regime of groundwater of the left coast upstream the dam near Novi Bečej. Water management 91-92, 407-416. (in Serbian)

Ducić, V., Radovanović, M. 2005. Climate of Serbia. Office for textbooks and teaching resources, Belgrade, $212 \mathrm{pp}$ (in Serbian).

Đurčić, R. 1984. Šid municipality. Faculty of Science, Institute of Geography, Novi Sad, 288 pp. (in Serbian)

Marković, S., Bogdanović, Ž. 1995. Relief influence on water regime of phreatic aquifer in Banat. Collection of papers of Institute of Geography 25, 11-20. (in Serbian)

Marković, S. 1996. Water regime and directions of phreatic aquifer drainage in Yugoslav part of Banat. Faculty of Science, Institute of Geography, Novi Sad, 82 pp. (in Serbian)

Milić, Č. 1973. Fruška gora. Matica Srpska, Department of Natural Sciences, Novi Sad, 74 pp. (in Serbian).

Milošev, Ž., Stojšić, M., Kukin, A. 1977. Influence of the Tisa slowdown to the groundwaters regime on its banks. Annual of the Provincial fund for waters "Vode Vojvodine" 5, 173-192. (in Serbian)

Pavić, D. 2006. Water Regime and Flow Directions of Phreatic Aquifer in Bačka. Faculty of Sciences, Department of Geography Tourism and Hotel Management, Novi Sad, 92 pp. (in Serbian)

Pavić, D., Lazić, L., Bogdanović, Ž., Plavša, J. 2006. Water Regime and the Direction of Drainage of Phreatic Aquifer in the Bačka Loess Plateau. Geographica Pannonica 10, 26-31.

Pavić, D., Mészáros, M., Curčić, G. 2012. Main Characteristics of Water Regime of the Phreatic Aquifer in Subotica Municipality (Vojvodina, Serbia). Geographica Pannonica 16 (4), 136-144.

Pennington, L.K., Cech, C. 2010. Water Resources and Enviromental Issues. Cambridge University Press, $457 \mathrm{pp}$.

Petrović, J., Bugarski, D., Curčić, D., Bogdanović, Ž. 1973. Waters of Fruška Gora. Matica Srpska, Department of Natural Sciences, Novi Sad, 68 pp. (in Serbian).

Rakićević, T. 1980. Climatic zoning of Federal Republic of Serbia. Journal of the Geographical Institute, Faculty of Sciences, Belgrade, 29-42 pp (in Serbian)

Stamenković, Lj. 2009. The use of Solar photovoltaic power in Serbia. Jefferson institute, Belgrade, 18 pp. (in Serbian).

Stojšić, M. 1994. Regimes and balances of groundwaters in Vojvodina. Collection of papers from counseling: Water, soil and agricultural chemistry: 2837. (in Serbian)

Turc, L. 1961. Estimation of irrigation water requirements, potential evapotranspiration: A simple climatic formula evolved up to date. Ann. Agronomy 12, 13-49. (in French)

Vasileva, D. 1978. Interrelations between groundwater and the Danube and their consequences. Water management 55, 12-17. (in Serbian)

Živković, B., Nejgebauer, V., Tanasijević, Đ., Miljković, N., Stojković, L., Drezgić, P. 1972a. Soils of Vojvodina. Institute for agricultural research, Novi Sad, 684 pp. (in Serbian)

Živković, B., Nejgebauer, V., Tanasijević, Đ., Miljković, N., Stojković, L., Drezgić, P. 1972b. Soils of Vojvodina - cartographic attachments. Institute for agricultural research, Novi Sad. (in Serbian)

Data base of Water management company "Šidina", Šid.

Data base of Statistical Office of the Republic of Serbia (2011).

Meteorological Yearbooks(1949-2011) of the Republic Hydrometeorological Service of Serbia, Belgrade.

Regional spatial plan of SAP Vojvodina. 1974. Provincial Secretariat of Urban Planning and Communal Affairs SAP Vojvodina, Novi Sad.

Topographic map. 1984. 1:25.000, Military-Geographical Institute, Belgrade.

Topographic map. 1983. 1:50.000, Military-Geographical Institute, Belgrade.

Pedological map of Vojvodina. 1971. 1:50.00o, Institute for agricultural research, Novi Sad. 